Original Research Article

\title{
Effect of educational intervention on knowledge, attitude and practice of hepatitis B vaccine among medical students
}

\author{
Sareetha A. V.*, Nagabushan H., Supriya K. H.
}

Department of Pharmacology, Mandya institute of Medical Sciences, Mandya, Karnataka, India

Received: 28 January 2018 Accepted: 06 March 2018

\section{*Correspondence to:}

Dr. Sareetha A. V.,

Email: dr.sarithaav@gmail.com

Copyright: (C) the author(s), publisher and licensee Medip Academy. This is an openaccess article distributed under the terms of the Creative Commons Attribution NonCommercial License, which permits unrestricted noncommercial use, distribution, and reproduction in any medium, provided the original work is properly cited.

\begin{abstract}
Background: Aim of the study were to assess the impact of education on knowledge, attitude and practice of Hepatitis B vaccine among medical students and to educate the students regarding Hepatitis B vaccination.

Methods: Non-randomized before and after comparison study was conducted to evaluate changes in knowledge, attitude and practice of Hepatitis B vaccination (HBV), assigning structured questionnaire of 26 different statements concerning knowledge, attitude and practice by pre and post educational intervention on Hepatitis B and its vaccination.

Results: The study was conducted among 100 second year medical students. The response rate was $100 \%$. There was statistically significant improvement in knowledge from pre-test mean scores for modes of transmission $(87.4+4.70 \mathrm{vs}$ $95.8+1.61 ; \mathrm{p}=0.0001)$, preventive measures $(92+0.47$ vs $98+0.94 ; \mathrm{p}=0.001)$ and Hepatitis $B$ vaccine $(71+4.72$ to $84.7+6.65 ; p=0.0001)$ to post-test. While the increase in mean scores from pre-test for attitude $(68.6+9.21$ vs $77.43+11.1)$ and practice $(55+25.41$ vs $65.6+32.6)$ were statistically significant in post-test $(\mathrm{p}=0.0001 ; \mathrm{p}=0.001$ respectively).

Conclusions: Structured educational intervention among medical students about Hepatitis B vaccination showed improved knowledge and behaviour and also increased the percentage of students willing to get screened and their participation in health education programmes related to Hepatitis B. However, there is slight lack of knowledge regarding the transmission of Hepatitis B and its vaccination schedule. In this regard, implementation and evaluation of educational intervention is needed as a preventative measure.
\end{abstract}

Keywords: Attitude, Educational intervention, Hepatitis B, Knowledge, Practice, Questionnaire

\section{INTRODUCTION}

Hepatitis is an acute systemic infection characterised by inflammation of liver caused by Hepatitis $B$ virus $(\mathrm{HBV}) .^{1,2}$

Globally, more than two billion people are affected with $\mathrm{HBV}$, and about 257 million people are chronic carriers of HBV. ${ }^{3}$ Of these, at least 6860000 people die annually due to acute or chronic liver disease, including cirrhosis and liver cancer as a consequence. ${ }^{4}$ However, the significance and magnitude of the problem vary from country to country. 5

India has intermediate endemicity of Hepatitis B, an estimate of $2-5 \%$ general population is chronically infected with hepatitis B..$^{4,6}$

HBV is 50 to 100 times more infectious than HIV. It is mainly acquired by accidental use of contaminated needles or blood products. ${ }^{7,8}$ 
Higher incidence of HBV among health care personnel is mainly due to contact with blood or body fluids of infected patients, contaminated needles and syringes injected into the skin or through accidental inoculation of minute quantities of blood during surgical procedures. ${ }^{9,10}$

Medical students being a part of the health care delivery system are exposed to the same. ${ }^{11}$ Though not greater, the magnitude of risk is high, similar to other health care workers when they come in contact with patients and contaminated instruments at the beginning of their clinical postings. ${ }^{5,12}$

Hepatitis B is preventable with safe and effective vaccines; and Hepatitis vaccine is the first vaccine developed against hepatocellular cancer. ${ }^{13}$ Although it does not cure the illness it is effective in preventing chronic infection and associated complications. ${ }^{14}$

Thus, knowledge regarding Hepatitis $\mathrm{B}$ infection, importance of vaccination as a preventable measure, undertaking simple hygienic measures and safety precautions are needed to minimize the acquired infection among medical students and health care personnel. ${ }^{11}$ The present study was conducted to evaluate the impact of education on knowledge, attitude and practice of HBV and also to educate the students regarding Hepatitis B vaccination so as to create awareness about the disease and its related morbidity and mortality.

\section{Objectives}

- To evaluate the knowledge of medical students on HBV vaccination.

- To assess the impact of education on Knowledge, Attitude and Practice of Hepatitis B vaccine among medical students.

- To educate the students regarding Hepatitis B vaccination.

\section{METHODS}

This was a non-randomized before and after questionnairebased comparison study conducted among second year medical students at Mandya Institute of Medical Sciences (MIMS), Mandya, between April 2017 to May 2017. A total of 100 students were enrolled in the study.

\section{Inclusion criteria}

- All the second year MBBS students of MIMS, Mandya.

\section{Exclusion criteria}

- Second year students who do not give consent.

- Those who are absent on the day of study.

The study was started after obtaining ethical clearance from the Institutional Ethics Committee MIMS, Mandya.
A pre-validated structured questionnaire comprising of questions on Knowledge, Attitude and Practice towards Hepatitis B and Hepatitis B vaccination was used. Before adaption of the questionnaire, thorough review and discussion were done with the faculty of Department of Pharmacology, MIMS, Mandya. Corrections and modifications were incorporated to obtain the final questionnaire. All the questions of questionnaire were closed ended questions with three options of $\mathrm{Yes} / \mathrm{No} / \mathrm{Do}$ not know.

After obtaining informed consent from the participating students, response rate was obtained. The assessment of their performance was based on the number of correct responses. This was followed by an educational intervention with power point presentation with regard to various aspects of $\mathrm{HBV}$, its modes of transmission, preventive measures and Hepatitis B vaccine schedule, its administration and doses. Two weeks after educational intervention, response rate to the same questionnaire was taken from the participants (Figure 1).

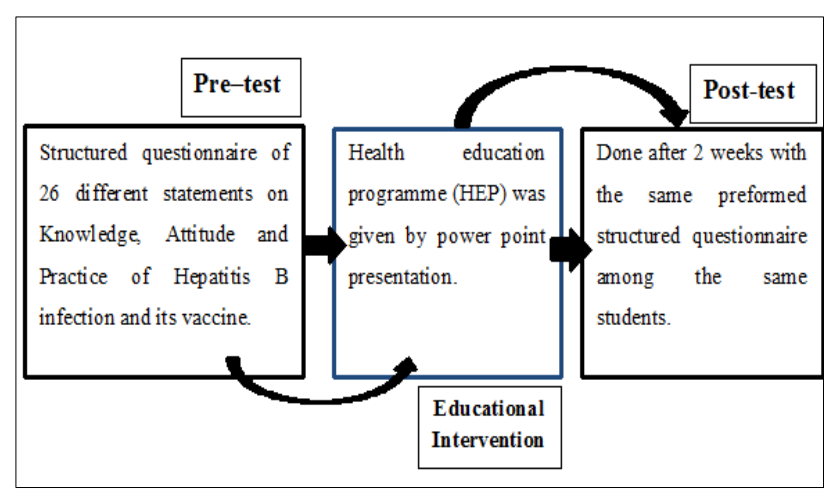

Figure 1: Description of the pre-test, educational intervention and post-test of KAP of Hepatitis B infection and Hepatitis $B$ vaccine.

\section{Statistical analysis}

Data was entered into Microsoft excel and analysis was done using Statistical Package for Social Sciences (SPSS) for Windows software (version 20; SPSS Inc, Chicago). Descriptive statistics such as percentage, mean, standard deviation and chi-square were determined. The $\mathrm{P}$ value less than 0.05 was considered to be statistically significant.

\section{RESULTS}

A total of 100 second year MBBS undergraduate students participated in the study. Among 100 students, 49\% were males and $51 \%$ were females. The response rate was $100 \%$.

Almost all the students (99\%) were aware that Hepatitis B is a virus infection (Table 1), and statistically significant improvement in level of knowledge with respect to modes of transmission $(95.8 \pm 1.61$ vs $87.4 \pm 4.7 ; \mathrm{p}=0.0001)$, preventive measures $(98 \pm 0.94$ vs $92 \pm 0.47 ; \mathrm{p}=0.001)$ and 
Hepatitis B vaccine $(84.7 \pm 6.65$ vs $71 \pm 4.72 ; p=0.0001)$ were reported in post-test compared to pre-test knowledge scores (Table 2).

An average of $79 \%$ of study participants had a positive attitude with regard to acceptance of infected hepatitis students and significantly greater percentage (82\% and
99\%) of the participants believed that HBV has drawn more attention as an occupational risk and its related training programmes are required to educate medical students when compared to pre-test $(55 \%$ and $88 \%$ respectively; $\mathrm{p}=0.0001 ; \mathrm{p}=0.0006)$ (Table 3 ).

Table 1: Comparison of responses on knowledge of Hepatitis $B$ and its vaccination before and after educational intervention.

\begin{tabular}{|lllll|}
\hline Knowledge based questions & \multicolumn{2}{l}{ Correct response (\%) } & $\chi^{2}$ & p value \\
\hline Transmission & Pre-test & Post-test & $\chi^{2}$ & 0.365 \\
\hline Hepatitis B is a virus & $96 \%$ & $99 \%$ & 0.821 & 0.36 \\
\hline $\begin{array}{l}\text { Hepatitis B can be transmitted by contaminated needle and infectious } \\
\text { blood or body fluids }\end{array}$ & $97 \%$ & $100 \%$ & 1.354 & 0.246 \\
\hline Trans-placental/vertical transmission of Hepatitis B does not occur & $68 \%$ & $90 \%$ & 13.291 & $0.0003^{* *}$ \\
\hline Hepatitis B cannot transmit through hand shaking/ coughing? & $86 \%$ & $94 \%$ & 2.722 & 0.099 \\
\hline $\begin{array}{l}\text { Liver disease can be caused by Hepatitis B virus if not treated or } \\
\text { prevented? }\end{array}$ & $90 \%$ & $96 \%$ & 1.920 & 0.165 \\
\hline Preventive measures & & & & \\
\hline $\begin{array}{l}\text { Does routine blood screening for HBsAg/ensuring of safe injection } \\
\text { practices prevent transmission }\end{array}$ & $91 \%$ & $96 \%$ & 1.316 & 0.251 \\
\hline $\begin{array}{l}\text { All haemodialysis patients, blood donors must be investigated for } \\
\text { Hepatitis B }\end{array}$ & $93 \%$ & $100 \%$ & 5.329 & $0.021^{+}$ \\
\hline Hepatitis B can be prevented by Hepatitis vaccination & $92 \%$ & $98 \%$ & 2.632 & 0.105 \\
\hline Hepatitis vaccine & $74 \%$ & $63 \%$ & 2.317 & 0.128 \\
\hline Hepatitis B is killed (inactivated) vaccine & $61 \%$ & $78 \%$ & 6.038 & $0.014^{+}$ \\
\hline It is safe for all age groups & $88 \%$ & $95 \%$ & 2.134 & 0.128 \\
\hline $\begin{array}{l}\text { Hepatitis B vaccine is included in Universal Immunization } \\
\text { Programme }\end{array}$ & $79 \%$ & $96 \%$ & 11.703 & $0.006^{*}$ \\
\hline $\begin{array}{l}\text { Hepatitis vaccine is recommended for 3 doses, given at 0,1 and 6 } \\
\text { months }\end{array}$ & $40 \%$ & $84 \%$ & 39.240 & $0.0001^{* *}$ \\
\hline Children <10 yr are given half of the adults dose & $84 \%$ & $92 \%$ & 2.320 & 0.128 \\
\hline Booster dose is recommended after primary Immunization? & & & \\
\hline
\end{tabular}

+ Statistically significant; *very significant; ** Extremely significant

Table 2: Comparison of the mean correct responses on knowledge of modes of transmission, preventive measures and Hepatitis $B$ vaccination before and after educational intervention.

\begin{tabular}{|lllll|}
\hline $\begin{array}{l}\text { Knowledge } \\
\text { domains }\end{array}$ & $\begin{array}{l}\text { Pre-test } \\
\text { Mean } \\
\mathbf{\pm S D}\end{array}$ & $\begin{array}{l}\text { Post-test } \\
\text { Mean } \\
\mathbf{\pm S D}\end{array}$ & $\chi^{2}$ & p value \\
\hline $\begin{array}{l}\text { Modes of } \\
\text { transmission }\end{array}$ & $87.40 \pm 4.7$ & $\begin{array}{l}95.8 \\
\pm 1.61\end{array}$ & 21.847 & $0.0001 * *$ \\
\hline $\begin{array}{l}\text { Preventive } \\
\text { measure }\end{array}$ & $92 \pm 0.47$ & $98 \pm 0.94$ & 10.140 & $0.001 *$ \\
\hline $\begin{array}{l}\text { Hepatitis B } \\
\text { vaccine }\end{array}$ & $71 \pm 4.72$ & $84.7 \pm 6.65$ & 51.242 & $0.0001 * *$ \\
\hline
\end{tabular}

Although the practice of Hepatitis B prevention by vaccination, or active screening, or usage of new syringes were almost similar between the pre and post-test participated students, there was a significantly greater percentage $(16 \%)$ of the participants who screened themselves for Hepatitis B in comparison to pre-test $(6 \%)$ $(\mathrm{p}=0.042)$ and $53 \%$ participants willing to participate in the health education programme in post-test when compared to pre-test $(26 \%)(\mathrm{p}=0.0002)$ (Table 4$)$.

\section{DISCUSSION}

According to World Health Organisation (WHO), Hepatitis B is a major health problem worldwide and a leading cause of morbidity and mortality. ${ }^{15}$

Occupational risk of Hepatitis B infection is well known in medical workers and among medical students during their professional training period. An estimate of 11 to $50 \%$ students get exposed to HBV infection during under graduation. ${ }^{16}$ 
Table 3: Attitude related to $\mathrm{HBV}$ and vaccination among the respondents.

\begin{tabular}{|lllll|}
\hline Attitude item & $\begin{array}{l}\text { Pre-test } \\
\text { satisfactory } \\
\text { response (\%) }\end{array}$ & $\begin{array}{l}\text { Post-test } \\
\text { satisfactory } \\
\text { response (\%) }\end{array}$ & $\chi^{2}$ & p value \\
\hline Hepatitis infected patients need to be isolated & $82 \%$ & $91 \%$ & 2.740 & 0.098 \\
\hline $\begin{array}{l}\text { Do you accept infected Hepatitis student in the same } \\
\text { college/ Institute/or eating from the same plate? }\end{array}$ & $67 \%$ & $79 \%$ & 3.070 & 0.079 \\
\hline $\begin{array}{l}\text { Do you feel confident in dealing with patient being } \\
\text { infected with Hepatitis B virus? }\end{array}$ & $70 \%$ & $84 \%$ & 4.771 & $0.029^{+}$ \\
\hline Attention drawn by occupational risk for Hepatitis is more & $55 \%$ & $82 \%$ & 15.664 & $0.0001^{* *}$ \\
\hline $\begin{array}{l}\text { Health care professional must receive Hepatitis B } \\
\text { vaccination }\end{array}$ & $94 \%$ & $95 \%$ & 0.096 & 0.756 \\
\hline $\begin{array}{l}\text { Training programmes are required to educate associated } \\
\text { occupational risk of Hepatitis B to all medical students }\end{array}$ & $88 \%$ & $99 \%$ & 8.227 & $0.004^{*}$ \\
\hline $\begin{array}{l}\text { Students get educated / ensured about Hepatitis B } \\
\text { vaccination by seminar, campaign and media awareness }\end{array}$ & $87 \%$ & $100 \%$ & 11.847 & $0.0006^{* *}$ \\
\hline Mean \pm SD & $68.6 \pm 9.21$ & $77.43 \pm 11.1$ & 38.887 & $0.0001^{* *}$ \\
\hline
\end{tabular}

Table 4: Practice related to Hepatitis B prevention among the students before and after educational intervention.

\begin{tabular}{|lllll|}
\hline Practice item & $\begin{array}{l}\text { Pre-test } \\
\text { satisfactory } \\
\text { response (\%) }\end{array}$ & $\begin{array}{l}\text { Post-test } \\
\text { satisfactory } \\
\text { response (\%) }\end{array}$ & $\chi^{2}$ & p value \\
\hline Have you got yourself vaccinated for Hepatitis B? & $62 \%$ & $68 \%$ & 0.549 & 0.458 \\
\hline Have you got yourself screened for Hepatitis B? & $6 \%$ & $16 \%$ & 4.137 & 0.420 \\
\hline $\begin{array}{l}\text { Do you want to screen blood for Hepatitis B before } \\
\text { blood transfusion? }\end{array}$ & $90 \%$ & $94 \%$ & 0.611 & 0.434 \\
\hline Do you ask for a new syringe before use? & $91 \%$ & $95 \%$ & 0.691 & 0.406 \\
\hline $\begin{array}{l}\text { Did you ever participate in health education } \\
\text { program related to Hepatitis B? }\end{array}$ & $26 \%$ & $53 \%$ & 14.149 & $0.0002^{* *}$ \\
\hline Mean \pm SD & $55 \pm 25.41$ & $65.6 \pm 32.6$ & 10.425 & $0.001^{*}$ \\
\hline
\end{tabular}

In this study, second year medical students were included. There were $49 \%$ males and $51 \%$ females. The response rate was $100 \%$, suggestive of students willingness to acquire knowledge about HBV and its vaccination. Similar results were seen in a previous study by Khan $\mathrm{N}$ et al. ${ }^{17}$

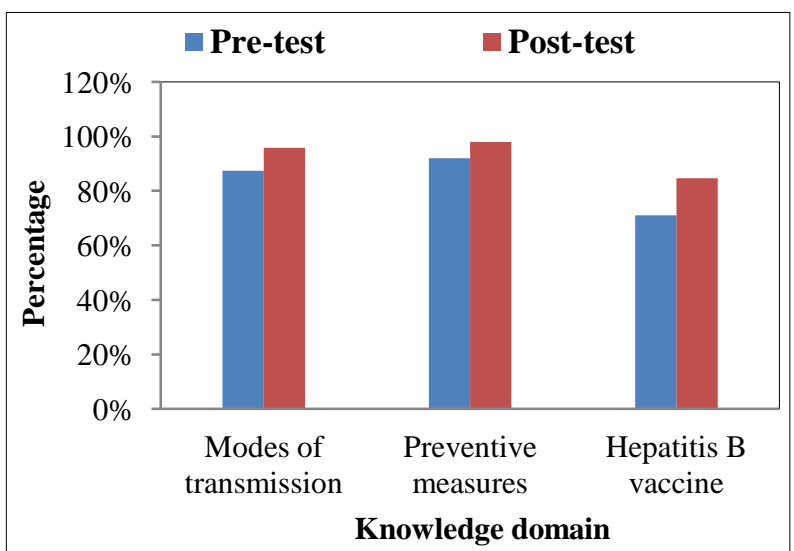

Figure 2: Comparison of the average correct responses on knowledge domains before and after educational intervention.
In this study, the improvement in knowledge score with regard to mode of transmission, preventive measures and Hepatitis B vaccination were statistically significant in post-test compared to the pre-test mean scores of $[95.8 \pm 1.61$ vs $87.40 \pm 4.70 \quad(\mathrm{p}=0.0001)], \quad[98 \pm 0.94$ vs $92 \pm 0.47 \quad(\mathrm{p}=0.001)]$ and $[84.7 \pm 6.65$ vs $71 \pm 4.72$ $(\mathrm{p}=0.0001)]$ respectively. The result shows statistically significant increase in knowledge score in the post-test (Figure 2).

These findings are consistent with Kumari P et al, study, in which participants scored higher in post-test $(8.44 \pm 1.869)$ compared to pre-test $(5.37 \pm 2.126)$ for the knowledge about teratogenicity $(\mathrm{p}=0.0003) .{ }^{18}$

In this study results are similar to a study conducted by Rani D et al. among nursing students, where results showed that mean score of pre and post-test for knowledge was higher in study group compared to control group (22.87 and 30.67 respectively). ${ }^{19}$

In this studyresults for attitude domain showed statistically significant difference in post-test when compared to pre- 
test with mean score $77.43 \pm 11.1$ vs $68.6 \pm 9.21$ respectively $(\mathrm{p}=0.0001)$. Analysis of mean change in attitude shows statistically significant improvement in post-test with a satisfactory attitude compared to pre-test $(\mathrm{p}=0.0001)$ (Figure 3).

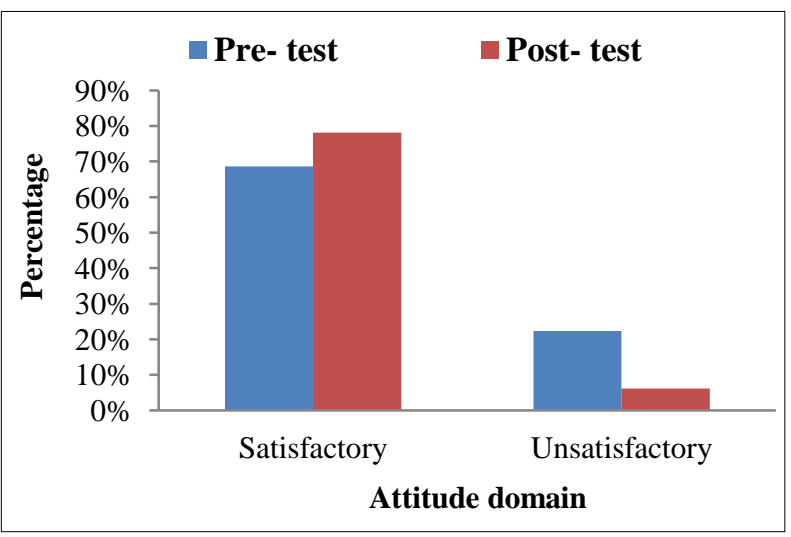

Figure 3: Comparison of responses to attitude in relation to $\mathrm{HBV}$ and Hepatitis $\mathrm{B}$ vaccination among respondents.

In this study results are similar to a study by Kumari $\mathrm{P}$ et al, the mean value of attitude score was higher in post-test group (3.61) compared to the pre-test group (3.30) $(\mathrm{p}=0.64){ }^{18}$

Another study by Nasser et al, suggested similar results that, convenient behaviour change among students was increased post intervention $(85.4 \%)$ when compared to pre-intervention $(55.3 \%){ }^{20}$

In this study, the level of improvement in practice was statistically significant in post-test with mean score $65.6 \pm 32.6$ compared to pre-test mean score of $55 \pm 25.41$ $(\mathrm{p}=0.001)$. The results proclaim that the HBV prevention can be accomplished by undertaking active participation in health education programmes, by screening and vaccination.

The findings of this study are similar to that of previous study performed by Bailoor et al, where there was statistically significant improvement in knowledge, its prevention and vaccination observed after education among dental professionals. $^{21}$

This study indicates that educational intervention given to medical students was an effective tool in improving the mean score for knowledge level, change in behaviour and practice in post-test when compared to pre-test and also highlights the scope for improvement with early intervention among students with regards to $\mathrm{HBV}$ and its vaccination.

The study has following limitations such as small scale study among medical students covering only one medical college. Selection bias due to study setting including only second year medical students. A pre-and post-assessment without follow up could not evaluate the long term effectiveness of this intervention on immunization coverage rate.

\section{Benefits}

Creating awareness about Hepatitis B virus transmission and Hepatitis B vaccination among the medical students who are at high risk for exposure

\section{CONCLUSION}

Medical students are commonly exposed to Hepatitis B that spreads by contact with an infected person's blood or other body fluids during their training period in hospital. Hence, knowledge about Hepatitis B is important among medical students. Structured education among medical students about Hepatitis B vaccine showed improved knowledge and behaviour and also increased the percentage of students willing to get screened for Hepatitis $\mathrm{B}$ and to participate in health education programme. However, there is slight lack of knowledge regarding the transmission and vaccination schedule. In this regards, implementation and evaluation of educational intervention is needed as a preventative measure.

\section{ACKNOWLEDGEMENTS}

Authors would like to thank all the second year medical students of MIMS who participated in the study and also the faculty of Department of Pharmacology for their help in structuring the questionnaire.

Funding: No funding sources Conflict of interest: None declared

Ethical approval: The study was approved by the Institutional Ethics Committee of MIMS, Mandya, India

\section{REFERENCES}

1. Monika MG, Santhosh KMP. Knowledge, Awareness and Attitude among dental Students about Hepatitis B Infection. J Pharm Sci and Res. 2016;8(3):168-70.

2. Al-Hazmi AH. Knowledge, attitude, and practice of medical students regarding occupational risks of hepatitis B virus in college of medicine, Aljouf University. Ann Med Health Sci Res. 2015;5:13-9.

3. World Health Organisation. Hepatitis B. Factsheet (updated july 2017) [Citied 2017 Jan 25]. Available at: http://www.who.int/mediacenter/factsheet/fs204/en/

4. Park K. Park's Textbook of Preventive and Social Medicine. 24 ${ }^{\text {th }}$ Ed. India: Bhanot Publishers; 2017:228.

5. Darwish MA, Al-Khaldi NM. Knowledge about Hepatitis B virus infection among medical students in university of Dammam, Eastern Region of Saudi Arabia. Life Science Journal. 2013;10(2):860-7.

6. Ray G. Current scenario of hepatitis B and its treatment in India. J Clin Transl Hepatol. 2017;5(3):277-96. 
7. Swarnalatha N. Do nursing students know about Hepatitis B? A study from nursing college in Tamil Nadu. International Journal of Health and Rehabilitation Sciences. 2014;3(2):69-74.

8. Kasetty S, Mohania A, Dwivedi D, Tijare M, Kallianpur S, Gupta S. A cross-sectional study on knowledge of Hepatitis B infection among dental professionals. Journal of virology and Microbiology. 2013;20(13):1-5.

9. Paudel DP, Prajapath SK, Paneru DP. Hepatitis B related knowledge and perception of nursing students: An Institutional based study in Kathmandu, Nepal. International Journal of Health Sciences and Research. 2012;2(8):57-66.

10. Nagpal B, Hegde U. Knowledge, attitude and practice of hepatitis B infection among dental students. Int $\mathbf{J}$ Med Scie Public Health. 2016;5(6):1123-7.

11. Singh A, Jain S. Prevention of Hepatitis B knowledge and practices among medical students. Indian Medical Gazette. 2012;1:52-56.

12. Nissar N, Baloach R, Munir AA. Does clinical experience affect knowledge regarding Hepatitis $\mathrm{B}$ among male medical students at a private university? J pak Med Assoc. 2009;59(12):808-11.

13. Rana SA, Ejaz A, Agha H, Fazal I. Awareness and frequency of hepatitis $B$ vaccination in high risk health care workers at a tertiary care hospital. Rawal Med J. 2013;38:3-6.

14. Kiran V. Hepatitis B vaccine introduction into the routine immunization schedule- Andhra Pradesh experience. Indian J public Health. 2004;48(2):63-6.

15. Shitoot AD, Motwani M, Chamele DP, Shitoot AP, Chamele J, Ghosh A. Hepatitis B awareness and attitudes among dental professionals in central India. J Indian Acad Oral Med Radiol. 2016;28:270-3.

16. Gioula G, Vasilakis T, Vassiliadou D, Xanthopoulos K, Triantafyllkai E, Kyriazopoulou-Dalaina V.
Knowledge of medical students about Hepatitis B. Aristotle university Medical Journal. 2008;35(3):55-8.

17. Khan N, Ahmed SK, Khalid MM, Siddiqui SH, Merchant AA. Effect of gender and age on the knowledge, attitude and practice regarding Hepatitis B and $\mathrm{C}$ vaccination status of Hepatitis $\mathrm{B}$ among medical students of Karachi, Pakistan. J Pak Med Assoc. 2010;60(6):450-5.

18. Kumari P, Krishnaiah V, Kumaraswamy G, Tamboli TJ. Impact of educational test on attitude towards teratogenicity among undergraduate medical students: a comparative study. Int $\mathrm{J}$ Basic Clin Pharmacol. 2017;6(11):2642-5.

19. Rani D. A study to assess the effectiveness of structured teaching programme on knowledge regarding Hepatitis $\mathrm{B}$ among nursing students in selected schools of nursing Moga, Punjab. Journal of Multidisciplinary research in healthcare. 2015;1(2):75-95.

20. El-Nasser GA, El-Baset EA. Assessment of students' knowledge and attitude towards Hepatitis B and C in Sohag University/Egypt. Kufa Journal for nursing sciences. 2013;3(1):1-14.

21. Bailoor DN, Rana T, Patel BJ. Knowledge, awareness and level of vaccination of Hepatitis B amongst the students of rural dental college, Uvarsad, Gandhinagar, Gujarat, India. J Educ Ethics Dent. 2012;2(2):69-73.

Cite this article as: Sareetha AV, Nagabushan H, Supriya KH. Effect of educational intervention on knowledge, attitude and practice of hepatitis B vaccine among medical students. Int J Basic Clin Pharmacol 2018;7:992-7. 